\title{
Locations and Chemistries of Sympathetic Nerve Cells that Project to the Gastrointestinal Tract and Spleen*
}

\author{
P. Trudrung, J. B. Furness, S. Pompolo and J. P. Messenger \\ Department of Anatomy and Cell Biology, University of Melbourne, Parkville, Australia
}

Received December 27, 1993

\begin{abstract}
Summary. Retrograde tracing was used to determine the locations of sympathetic nerve cells whose axons project to the stomach, small intestine, caecum, proximal colon, distal colon and spleen of the guinea-pig. Projections from prevertebral ganglia were organotopically arranged within and between ganglia. The cranially located coeliac ganglion provided the major input to proximal gut regions; the distal gut received more caudal input, from superior and inferior mesenteric and the hypogastric nerve ganglia. Nevertheless, minor proportions of the innervation of some target organs arose from other than the closest ganglion and the caecum had input from each of the coeliac, superior mesenteric and inferior mesenteric ganglia. Topography within a ganglion was best defined in the coeliac, in which nerve cells whose axons projected to the spleen, stomach and duodenum were preferentially laterally located, whereas most of those projecting to the proximal colon were medial. Fewer neurons projected from paravertebral-compared with prevertebral-ganglia to abdominal viscera. Projections to the stomach came from all thoracic chain ganglia, those to the duodenum and spleen from lower thoracic ganglia and those to the large intestine from lumbar chain ganglia. It is suggested that the previously reported chemical topography of nerve cells in sympathetic ganglia might be secondary to their organotopic organization.
\end{abstract}

Topographic mapping between groups of nerve cells and their targets is a general feature of the nervous system which is well demonstrated by the relations between motor neuron pools and somatic muscle (ROMANES, 1964). Somatotopic relations also occur for sympathetic preganglionic neurons and target neurons in sympathetic chain ganglia that subserve specific functions (LANGLEY, 1892; NJÅ and PURVES,
1977). Moreover, neurons supplying specific organs tend to be located selectively in regions of sympathetic chain ganglia, though these regions overlap (LICHTMAN et al., 1979; DAIL and BARTON, 1983; KEAST et al., 1989).

A chemical topography occurs within the coeliac ganglion of the guinea-pig (LINDH et al., 1986; MACRAE et al., 1986), in which somatostatin immunoreactive neurons are preferentially located medially and neuropeptide Y (NPY) immunoreactive neurons are lateral. It has been assumed that this represents a partial segregation of neurons by function, the somatostatinimmunoreactive being involved in the control of secretomotor reflexes in the intestine and the NPYimmunoreactive neurons being involved in vascular control. This is likely a simplistic interpretation in that it derives from a consideration only of the efferent projections to the small intestine (COSTA and FURNESS, 1984). The coeliac ganglion also has major projections to the stomach, spleen and proximal large intestine, all targets which require consideration in any analysis of ganglion topography. Moreover, the ganglia appear to be topographically organised in relation to their connecting trunks: KREULEN and SZURSZEWSKI (1979) reported that nerve cells were most likely to receive synaptic input from nerve connectives nearest them. This suggests that an organrelated topography, perhaps superimposed on the functional topography that had been assumed, exists in the coeliac ganglia. Neverthless, not all projections to abdominal organs arise from cell bodies of the most proximate ganglia. For example, some sympathetic neurons that supply abdominal viscera have cell bodies in sympathetic chain ganglia (LUNDBERG et al., 1978; KUO and KRAUTHAMER, 1991; HILL et al.,

${ }^{*}$ This work was supported by a grant from the National Health and Medical Research Foundation of Australia.

Dr. TRudRung was a Research Scholar under the Australian-European Awards Program. 
1987; JÄNIG and MCLACHLAN, 1987; HUdSON, 1989) and some nerve cells of prevertebral ganglia have axons that traverse other prevertebral ganglia before running towards abdominal viscera (DALSGAARD and ELFVIN, 1982; KING and SzURSZEWSKI, 1989; PARR et al., 1993).

The present work was undertaken to determine which para- and prevertebral ganglia project to restricted gut regions and the spleen, and to what extent an organ-related topography and neurochemistry exists in the prevertebral ganglia.

\section{MATERIALS AND METHODS}

Experiments were performed on adult guinea-pigs of both sexes in the weight range $200-300$ g. For retrograde tracing and surgery, the guinea-pigs were anesthetized with a subcutaneous injection of sodium pentobarbitone, $15 \mathrm{mg} / \mathrm{kg}$, and intramuscular fentanyl, 0.6 $\mathrm{mg} / \mathrm{kg}$, and fluanisone, $5.0 \mathrm{mg} / \mathrm{kg}$. Animals were killed by a blow to the occipital region and by severing the carotid arteries.

\section{Retrograde tracing}

Guinea-pigs were deprived of food overnight prior to surgery. They were anaesthetized and the abdomen was opened by a midline abdominal incision to expose the spleen or appropriate region of the gastrointestinal tract. Organs were injected with Fast Blue (Sigma, St. Louis, Mo., USA), 4\% in 10\% dimethylsulphoxide in distilled water via a bevelled glass micropipette of tip diameter $70-100 \mu \mathrm{m}$. Fast Blue was injected at multiple sites in each organ (see Table 1 for injection sites and number of animals). In separate experiments the ventral and dorsal gastric walls were each injected at 15 sites spaced approximately equally apart in an arc from the gastroduodenal to the gastroesophageal junction. The first $4-5 \mathrm{~cm}$ of the

Table 1. Injection sites and numbers of animals

\begin{tabular}{lc}
\hline Injection site & Number of animals \\
\hline Stomach, ventral wall & 6 \\
Stomach, dorsal wall & 3 \\
Duodenum & 5 \\
Proximal and distal small intestine & 3 \\
Caecum & 3 \\
Proximal colon & 3 \\
Distal colon & 3 \\
Spleen & 3 \\
Intermesenteric nerve dip & 6 \\
\hline
\end{tabular}

ventral surface of the duodenum was also injected at 15 sites. The splenic injections were at 10 sites at its more accessible (ventral) end. Fifteen injections were made in the caecum, 9 into the wall between the taenia and 6 beneath the taenia. In the proximal colon, 15 sites approximately equally spaced along its length were injected. The distal colon was also injected at 15 sites extending from 1 to $5 \mathrm{~cm}$ proximal to the pelvic brim. In 3 animals, 10 injections were made in the duodenum and another 10 in the most distal $10 \mathrm{~cm}$ of small intestine. Injections were made under stereomicroscopic guidance by pushing the tip of the micropiptette at a low angle into the wall of the gut or into the spleen. For gastrointestinal injections, the tip was usually located in the external musculature or submucosa. Individual injection volumes were about $0.5 \mu 1$.

In order to determine the origin of axons of the intermesenteric nerve, the supporting connective tissue sheet was cut parallel to the intermesenteric nerve on both sides and a small piece of parafilm was inserted through the cuts and underneath the nerve. A well was fashioned from petroleum jelly on the parafilm base and the intermesenteric nerves were transected in the well. The cut ends were maintained in droplets of $4 \%$ Fast Blue in 10\% DMSO for 15 min.

At the completation of all surgical procedures, the peritoneum and abdominal muscles were sewn together and the skin was stapled. Each animal received a $0.1 \mathrm{ml}$ intramuscular injection of Terramycin (200 mg/ml; Pfizer, West Ryde, Australia), a broad spectrum antibiotic.

\section{Removal of ganglia}

The animals were killed four to seven days after the injection of Fast Blue. The sympathetic chains on both sides, from the stelleate ganglia (T1) to the first sacral ganglia (S1) and the coeliac, superior mesenteric, inferior mesenteric, and anterior pelvic ganglia, were removed. The hypogastric nerves were removed with the anterior pelvic ganglia. The small ganglia along these nerves, just cranial to the anterior pelvic ganglia, are referred to in the present work as the hypogastric nerve ganglia (HNG). During dissection, the ganglia and nerve trunks were kept moist with phosphate-buffered saline (PBS; $0.9 \% \mathrm{NaCl}$ in $0.01 \mathrm{M}$ sodium phosphate buffer, $\mathrm{pH}$ 7.0). The ganglia were pinned to sheets of dental wax and then submerged in a fixative $[2 \%$ formaldehyde plus $0.2 \%$ picric acid ( $15 \%$ of a saturated solution) in $0.1 \mathrm{M}$ sodium phosphate buffer, $\mathrm{pH} 7.0]$ for $24 \mathrm{~h}$ at $4^{\circ} \mathrm{C}$. After fixation, the tissue was washed in dimethylsulphoxide $(3 \times 10$ min) followed by PBS $(3 \times 10 \mathrm{~min})$. The sympathetic 
chains were then rinsed in distilled water and laid out on dry poly-L-ornithine coated microscope slides. Excess moisture clinging to the chains was removed with filter paper and the chains, on the microscope slides, were placed under a vacuum in a desiccator containing $\mathrm{P}_{2} \mathrm{O}_{5}$ for 30 min to $1 \mathrm{~h}$. The dried chains were mounted in buffered glycerol $(\mathrm{pH} 8.6)$ and coverslipped. Prevertebral ganglia were immersed in PBS containing $30 \%$ sucrose and $0.1 \%$ sodium azide overnight, or until taken for sectioning at $10-14 \mu \mathrm{m}$ on a cryostat.

\section{Immunohistochemistry}

Serial sections were taken and grouped on slides so that sections that were 6 apart were stained together, i.e., the 1st, 7th etc sections were double stained for somatostatin and NPY, and the 2nd, 8th etc were used only for counting retrogradely labelled cells. Sections for immnohistochemistry were air dried for one hour and non-specific binding sites were blocked with $10 \%$ horse serum. This was followed by incubation with a mixture of primary antibodies for $48 \mathrm{~h}$ in a humid chamber at room temperature. These were anti-NPY raised in a rabbit (MACCARRONE and JARROTT, 1985) and a monoclonal (mouse) anti-SOM (BUCHAN et al., 1985). After removing the primary antibodies with PBS, immunoreactivity was localized using biotinylated and fluorescein-labelled secondary antisera. NPYimmunoreactivity was revealed with fluorescein-isothiocyanate (FITC) conjugated secondary antibody (2 h, final dilution 1:160; Wellcome Diagnostics), and somatostatin-immunoreactivity by biotinylated horse anti-mouse antibody ( $2 \mathrm{~h}$, final dilution $1: 200$; Vector Laboratories, Burlingame, CA, USA). After washing in PBS, biotinylated secondary antibodies were revealed with a streptavidin-Texas Red complex $(2 \mathrm{~h}$, $1: 50$ final dilution; Amersham), washed in PBS and the slides coverslipped with buffered glycerol ( $\mathrm{pH}$ 8.6) and analysed under a Zeiss Axioplan epifluorescence microscope equipped with selective filter blocks for Fast Blue, FITC and Texas Red. For photography, Kodak Ektachrome (ASA 160 set to 320) and Kodak T MAX (ASA 400 set to 1000) film (Kodak, Rochester, NY, USA) were used.

\section{Quantitation}

The sympathetic chains and the hypogastric nerve ganglia were prepared as whole mounts and all labelled cells were counted. The prevertebral ganglia were sectioned flat (in the coronal plane; MACRAE et al., 1986). Representative cell counts were made from single sections through the centres of the ganglia. In addition, the ratios of immunochemically labelled cells were determined in sections counterstained for somatostatin or NPY, also through the centres of ganglia.

\section{RESULTS}

\section{Distribution of nerve cells projecting to the gastro- intestinal tract and spleen}

Examples of Fast Blue labelled nerve cells in prevertebral and paravertebral chain gabglia after injection into different regions of the gastrointestinal tract are illustrated in Figure 1, and the distributions are summarised in Figure 2. For each organ, the number and placement of injections of Fast Blue were kept as constant as could be managed. Nevertheless, outcomes varied. In general, the major groups of labelled cells were consistent between experiments and trends were similar. The types of variation that occurred were the extent of the sympathetic chain that contained labelled nerve cells, the absolute numbers of cells labelled and the intensity of labelling. The numbers of ganglia in the sympathetic chains vary between animals and between sides in the same animal. For example, L1 and L2 ganglia were often fused. In the summary diagrams of Figure 2, we have idealished the ganglia and amalgamated the individual observations.

In guinea-pigs, the two hypogastric nerves are well defined and extend from the posterior poles of the inferior mesenteric ganglia to the anterior pelvic ganglia (Fig. 2). About $1 \mathrm{~cm}$ before it reaches the anterior pelvic ganglion, each hypogastric nerve spilits into a narrow fan of 4 to 5 major branches and a number of minor branches. Most of the branches appear to join the anterior pelvic ganglion. Within the fan are several small ganglia, containing from tens to hundreds of nerve cells. Small ganglia are also found along the nerve before it branches. In the present work, retrogradely labelled cells were found in the hypogastric nerve ganglia of the most posterior $1 \mathrm{~cm}$ of the hypogastric nerve, but not in the anterior pelvic ganglia.

\section{Gastric injections}

Following injections into the gastric wall, labelled nerve cells were found in thoracic sympathetic chain ganglia, from $\mathrm{T} 1$ to T12, but not in lumbar chain ganglia. The ganglia were viewed as whole mounts, so the full complement of nerve cells in each ganglion could be counted. Most ganglia contained an average of 2 to 10 nerve cells (range $0-41$ ), which is a very small proportion of their total populations (GIBBINS, 

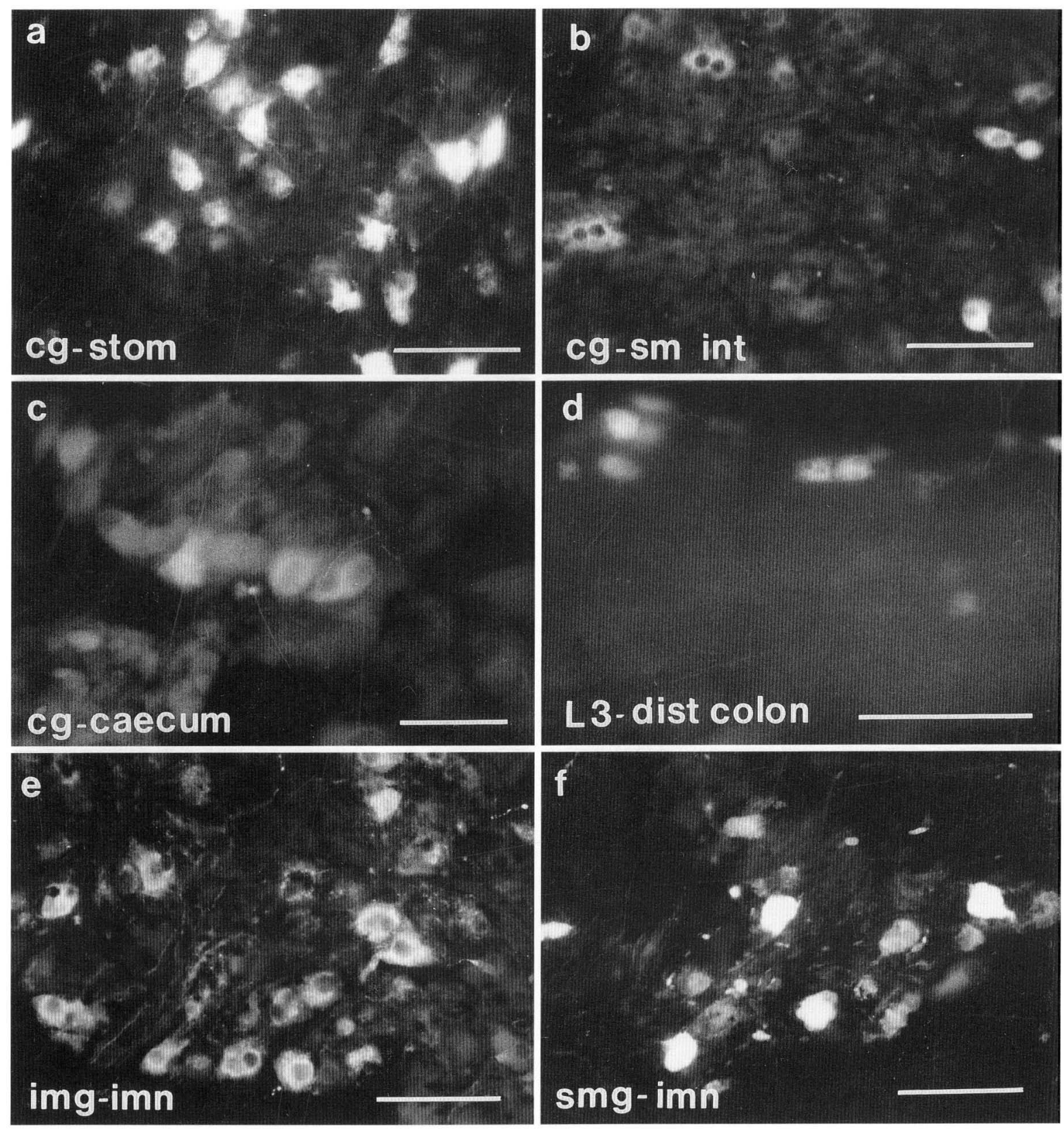

Fig. 1. Examples of retrogradely labelled neurons in sympathetic ganglia. a. Cells in the coeliac ganglion following the injection of Fast Blue into the ventral wall of the stomach. b. Cells in the coeliac ganglion following the injection of Fast Blue into the wall of the small intestine. c. Fast Blue cells in the coeliac ganglion after injection of the caecal wall. d. Labelled neurons in a whole mount of the L3 paravertebral ganglion after injection of the wall of the distal colon. e. Cells labelled in the inferior mesenteric ganglion after the cut intermesenteric nerves were immersed in Fast Blue. f. Cells in the superior mesenteric ganglion that have been labelled by immersion of the cut intermesenteric nerves. Calibrations: $50 \mu \mathrm{m}$ 

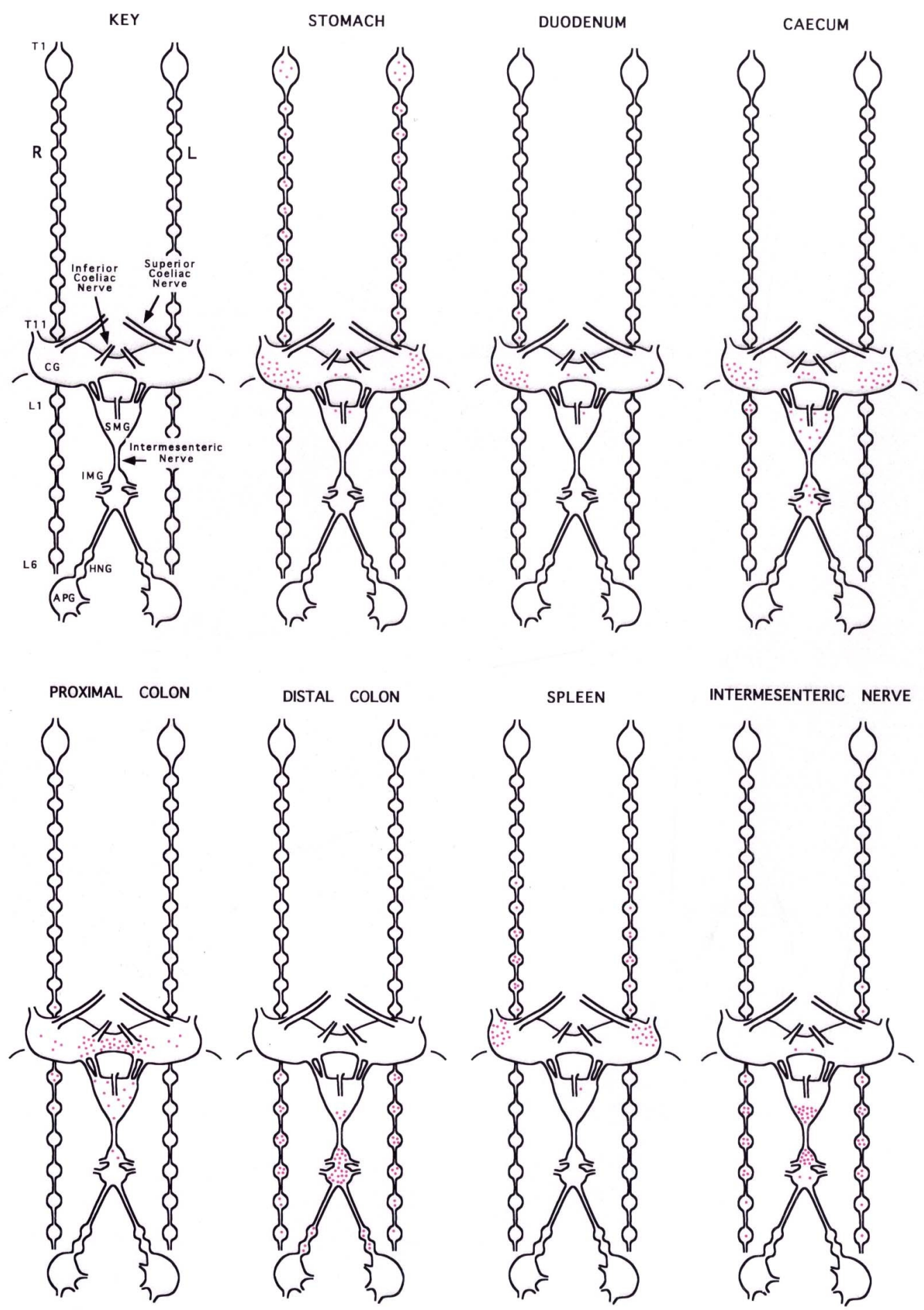

Fig. 2. Diagrammatic representations of the locations of labelled nerve cells after injection of target organs. The diagram labelled "KEY" provides a guide to structures in the following diagrams, for which the organs injected are indicated. T1 first thoracic ganglion, T11 eleventh thoracic ganglion, $L 1$ first lumbar ganglion, $L 6$ sixth lumbar ganglion, $C G$ coeliac ganglion, $S M G$ superior mesenteric ganglion, $I M G$ inferior mesenteric ganglion, $H N G$ hypogastric nerve ganglia, $A P G$ anterior pelvic ganglion, $R$ right side of guinea-pig, $L$ left side of guinea-pig. 
1992). Anterior wall injections labelled more cells in the stellate (T1) ganglia (average 13, range 3-30) than in other thoracic ganglia. Amongst the other ganglia, most cells were in T4 to T9 ganglia, averaging about 5 nerve cells per ganglion. More cells were labelled in the left chain (average 79) than in the right chain (average 36).

Injections into the posterior wall produced a preponderance of cells at T8 to T11, with most at T10. As for anterior wall injections, more cells were labelled in the left chain (average 50) compared with the right (average 33). At T10, there was an average of 12 labelled cells (range 6-20) on the right and 19 (range 2-45) on the left. In conrast to the anterior wall injections (average 13 neurons), an average of only 3 neurons was labelled in T1 when the injections were confined to the posterior gastric wall.

About 200 labelled nerve cell bodies were found in single coronal sections through the coeliac ganglion, mostly in its lateral poles, after either anterior or posterior wall injection (Fig. 1a). In contrast, only one of the 9 gastric injection experiments resulted in labelled cells in the superior mesenteric ganglion, with only 20 cells found, in total, across all sections. No nerve cells were labelled in the inferior mesenteric, hypogastric nerve or anterior pelvic ganglia.

\section{Small intestine injections}

In five animals, injections were confined to the duodenum (first $4-5 \mathrm{~cm}$ of the small intestine), and in three animals both the duodenum and the last $10 \mathrm{~cm}$ of the ileum were injected. After duodenal injection, labelled cells were found in the thoracic chain (T9-12) on the right only in each animal, with the maximum number of cells being 5 at T9 (range $0-10$ ). In one animal, one cell was at each of L1 and L2. More cells were labelled in the paravertebral chains after duodenal plus distal ileum injections, and they extended from T3 to L3. Maxima were 14 (range $0-32$ ) at T12 on the right and 15 (range $3-28$ ), also at T12, in the left chain.

Duodenal or duodenal plus distal ileum injections labelled 43-80 nerve cells per coronal section in the coeliac ganglion in all 8 experiments. After duodenal injection, labelled cells were found predominantly in the lateral part of the right lobe, but after injection at both ends of the intestine, cells were spread across the ganglion (Fig. 1b). A small number of cells was found in the superior mesenteric ganglia in 2 of 5 duodenal experiments and in 2 of 3 where both ends of small intestine were injected for a total of 2-7 labelled cells found. Labelled nerve cells were found in the inferior mesenteric ganglia in only 1 case (duodenal injection), but there were only 2 cells. No labelled cells were found in the hypogastric nerve ganglia or the anterior pelvic ganglia.

\section{Caecum injections}

In all 3 experiments, labelled nerve cells were found in the right lumber chain from L1-L3. No cells were found in the thoracic chian ganglia or on the left side. There was an average of 36 labelled cells at L1. Labelled nerve cells were most numerous in the coeliac ganglion (100 per coronal section), where they were bilaterally located, and were also found in the superior mesenteric (35 per section) and in the inferior mesenteric ganglia (30 per section) of all animals. No labelled cells appeared in the ganglia of the hypogastric nerves.

\section{Proximal colon injections}

Labelled nerve cells were found in the right chain ganglia only, from T11 to L2. Cell numbers in the thoracic chain ganglia were low ( $0-3$ per ganglion), but averaged 15 at $\mathrm{L} 1$, reducing to $0-2$ at L2. In prevertebral ganglia, labelled cells were most numerous in the medial part of the coeliac (about 100 per coronal section), were frequent in the superior mesenteric (about 30 per section) and were rare but consistent in the inferior mesenteric ganglia (about 3 per section). There were no labelled cells in the hypogastric nerve or anterior pelvic ganglia.

Table 2. Labelled cells in the coeliac ganglia

\begin{tabular}{|c|c|c|c|}
\hline & $\mathrm{FB} /-$ & $\mathrm{FB} / \mathrm{NPY}$ & $\mathrm{FB} / \mathrm{SOM}$ \\
\hline \multicolumn{4}{|l|}{ Stomach injection } \\
\hline \multicolumn{4}{|l|}{1155 cells in total } \\
\hline Right/Mid/Left & $315 / 36 / 267$ & $189 / 11 / 218$ & $49 / 20 / 50$ \\
\hline Population (\%) & 54 & 36 & 10 \\
\hline \multicolumn{4}{|l|}{ Duodenum injections } \\
\hline \multicolumn{4}{|l|}{80 cells in total } \\
\hline Right/Mid/Left & $14 / 0 / 2$ & $46 / 3 / 0$ & $15 / 0 / 0$ \\
\hline Population (\%) & 20 & 61 & 19 \\
\hline \multicolumn{4}{|l|}{ Caecum injections } \\
\hline \multicolumn{4}{|l|}{728 cells in total } \\
\hline Right/Mid/Left & $110 / 0 / 142$ & $126 / 0 / 218$ & $27 / 74 / 31$ \\
\hline Population (\%) & 35 & 47 & 18 \\
\hline \multicolumn{4}{|c|}{ Proximal colon injections } \\
\hline \multicolumn{4}{|l|}{213 cells in total } \\
\hline Right/Mid/Left & $19 / 0 / 21$ & $25 / 0 / 16$ & $0 / 132 / 0$ \\
\hline Population (\%) & 19 & 19 & 62 \\
\hline \multicolumn{4}{|c|}{$\begin{array}{l}\text { Numbers of nerve cells containing Fast Blue alone (FB } \\
\text { /-), Fast Blue plus NPY-IR (FB/NPY) and Fast Blue plus } \\
\text { somatostatin (FB/SOM) in the right lateral (Right), } \\
\text { medial (Mid) and left lateral (Left) parts of the coeliac } \\
\text { ganglion after different organ injections. }\end{array}$} \\
\hline
\end{tabular}




\section{Distal colon injections}

Labelled nerve cells were found in lumbar, but not in thoracic ganglia of all three animals. They were high in numbers, and extended from $\mathrm{L} 1$ to S1. They were most numerous at L2-L4, with peak averages of 55 (range 23-71) in the right chain and 41 (range 20-53) in the left chain (Fig. 1a). Overall, there was no rightleft bias. Labelled cells were found in the caudal (inferior) pole of the superior mesenteric ganglion, both lobes of the inferior mesenteric ganglia in greatest numbers, and in the hypogastric nerve ganglia, but not in the anterior pelvic or coeliac ganglia. Axons could be traced from labelled nerve cells in the hypogastric nerve ganglia; these axons ran posteriorally, towards the anterior pelvic ganglia.

\section{Spleen injections}

In contrast to injections in the gastrointestial tract, the majority of nerve cells labelled from the spleen were found in paravertebral, rather than prevertebral ganglia. Cells were found from T6 to T11, with an average of 65 cells in the right chains and 22 in the left. On both sides, the peak was at T10, with an average of 28 (range 12-55) neurons on the right and 13 (range 1-30) neurons on the left. There was an average of 8 neurons per coronal section of the coeliac ganglion, and labelled nerve cells were found

Table 3. Labelled cells in superior mesenteric ganglia

\begin{tabular}{|c|c|c|c|}
\hline & $\mathrm{FB} /-$ & $\mathrm{FB} / \mathrm{NPY}$ & $\mathrm{FB} / \mathrm{SOM}$ \\
\hline \multicolumn{4}{|l|}{ Caecum injections } \\
\hline \multicolumn{4}{|l|}{34 cells in total } \\
\hline Number & 2 & 17 & 15 \\
\hline Population (\%) & 6 & 50 & 44 \\
\hline \multicolumn{4}{|c|}{ Proximal colon injections } \\
\hline Number & 9 & 28 & 22 \\
\hline Population (\%) & 15 & 48 & 37 \\
\hline \multicolumn{4}{|c|}{ Distal colon injections } \\
\hline \multicolumn{4}{|l|}{95 cells in total } \\
\hline Number & 26 & 33 & 36 \\
\hline Population (\%) & 27 & 35 & 38 \\
\hline \multicolumn{4}{|c|}{$\begin{array}{l}\text { Intermesenteric nerve cut and dip } \\
675 \text { cells in total }\end{array}$} \\
\hline Number & 421 & 152 & 102 \\
\hline Population (\%) & 62 & 23 & 15 \\
\hline
\end{tabular}

Numbers and percentages of nerve cells containing Fast Blue alone (FB/-), Fast Blue plus NPY (FB/NPY) and Fast Blue plus somatostatin $(\mathrm{FB} / \mathrm{SOM})$ in the superior mesenteric ganglia after different organ injections. in the superior mesenteric ganglion of only 1 of the 3 animals, in which 3 were present. No labelled cells were in the inferior mesenteric, hypogastric nerve or anterior pelvic ganglia.

\section{Labelling from the intermesenteric nerves}

The observation that nerve cells are labelled in the coeliac or superior mesenteric ganglia and in the inferior mesenteric ganglia after some injections of individual organs implies that some axons of prevertebral noradrenergic neurons follow the intermesenteric nerves and traverse other ganglia to reach the gut. To test this conclusion, the intermesenteric nerves were severed and dye applied to each of the cut ends.

Labelled nerve cells were found in the sympathetic chains, the coeliac, superior mesenteric and inferior mesenteric ganglia (Fig. 3e, f). In two experiments out of seven, up to five labelled nerve cells were found in the left lower thoracic ganglia. In the lumbar chain, labelling was seen throughout, averaging 9 (range 0 18) and 13 (range 4-19) cells in the right and left L1, respectively, 44 (range $0-104$ ) and 36 (range $3-57$ ) in the right and left L2, 45 (range 12-79) and 25 (range $3-86$ ) in the right and left L3, 14 (range 0-46) and 14 (range 4-37) in the right and left L4. In the L5, L6 and lumbar-sacral ganglia much less labelling was observed, with averages between 0.6 and 2 (range 0 7). Overall, slightly more labelled cells were found in the right lumbar chain (576), compared with the left (482).

Table 4. Labelled cells in inferior mesenteric ganglia

\begin{tabular}{lccc}
\hline & FB/- & FB/NPY & FB/SOM \\
\hline Caecum injections & & & \\
28 cells in total & & & \\
$\quad$ Number & 3 & 13 & 12 \\
Population (\%) & 11 & 46 & 43 \\
\hline $\begin{array}{l}\text { Distal colon injections } \\
\text { 163 cells in total }\end{array}$ & & \\
$\quad$ Number & 54 & 74 & 35 \\
Population (\%) & 33 & 45 & 22 \\
\hline $\begin{array}{l}\text { Intermesenteric nerve cut and dip } \\
\text { 310 cells in total }\end{array}$ & & \\
Number & 185 & 72 & 53 \\
Population (\%) & 60 & 23 & 17 \\
\hline
\end{tabular}

Numbers and percentages of nerve cells containing Fast Blue alone (FB/-), Fast Blue plus NPY (FB/NPY) and Fast Blue plus somatostatin $(\mathrm{FB} / \mathrm{SOM})$ in the inferior mesenteric ganglia after different organ injections. 

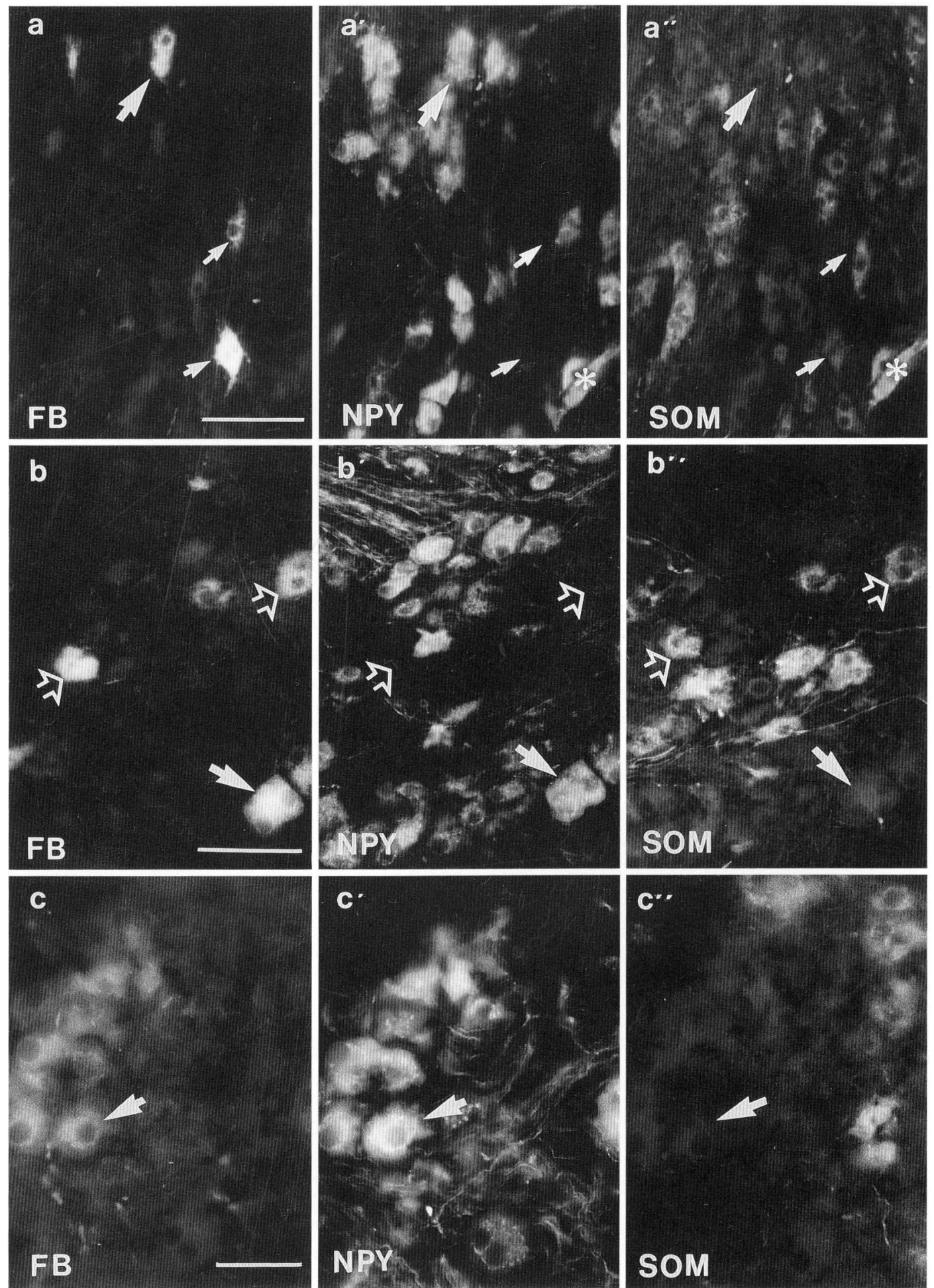

Fig. 3. Immunohistochemical localization of neuropeptide $\mathrm{Y}(N P Y)$ and somatostatin $(S O M)$ in sections containing Fast Blue labelled nerve cells. The Fast Blue was retrogradely transported from the small intestine to the coeliac ganglion (a), the caecum to the superior mesenteric ganglion (b) and the intermesenteric nerves to the coeliac ganglion (c). Example of Fast Blue labelled nerve cells are indicated by arrows; small arrows indicate cells that were not immunoreactive for either peptide, large arrows indicate labelled neurons that were NPY-reactive and open arrows point to cells that were somatostatin-reactive. Calibrations: $50 \mu \mathrm{m}$. 
In the prevertebral ganglia, labelled cells were most numerous in the rostral lobe of the inferior mesenteric ganglion (about 100 cells per coronal section) and the caudal part of the superior mesenteric ganglion (about 200 cells per coronal section), less frequent in the caudal lobe of the inferior mesenteric ganglion (about 20 cells per coronal section), and inconsistently found in the medical part (up to 10 cells per section) of the coeliac ganglion. No labelled cells were found in the hypogastric nerve ganglia, the anterior pelvic ganglia or the lateral lobes of the coeliac ganglion.

\section{Neurochemical coding of retrogradely labelled nerve cells in prevertebral ganglia}

Nerve cells were divided into three groups: those that were retrogradely labelled and were also immunoreactive for NPY (FB/NPY neurons); those that were also immunoreactive for somatostatin (FB/somatostatin neurons); and those which were retrogradely labelled, but were not immunoreactive for either peptide (FB/- neurons) (Fig. 3; Tables 3, 4).

\section{Gastric injections}

Following injections into the gastric wall, about 55\% of labelled cell bodies in the coeliac ganglion were neither NPY nor SOM reactive. Fast Blue/NPYimmunoreactive cells comprised about $35 \%$ whereas the proportion of Fast Blue/SOM cells was only about 10\% (Table 2).

Retrogradely labelled nerve cells were detected in the superior mesenteric ganglion in only one of the nine gastric wall injection experiments. In this one case, a total of 20 Fast Blue-labelled cells were detected in serial sections through the ganglion. In a double stained section, 2 were negative for both NPY and SOM, 3 were positive for NPY, but none for SOM.

\section{Small intestine injections}

After duodenal injections, Fast Blue-labelled cells were predominantly located in the right lobe of the coeliac ganglion, where most cells had NPY-immunoreactivity. Fast Blue cells with somatostatin-immunoreactivity or with no immunoreactivity for either peptide were in about equal numbers (Table 2; Fig. 3a).

Neurochemical analysis of the few labelled cells found in the superior mesenteric and inferior mesenteric ganglia was not undertaken.

A more widespread occurrence of Fast Blue cells was observed in the coeliac ganglion after combined duodenal and small intestinal injections. However, the neurochemical coding of the labelled cells did not differ much from the findings after duodenal injections. In two of three experiments, Fast Blue-labelled cells were found in the superior mesenteric ganglion, their number being too low for a more detailed analysis.

\section{Caecum injections}

In all three experiments, labelled nerve cells were found bilaterally in the coeliac ganglia, in the superior and inferior mesenteric ganglia.

In the coeliac ganglion, Fast Blue cells with NPYimmunoreactivity formed the biggest subgroup, followed by Fast Blue cells negative for both NPY and SOM: the Fast Blue/somatostatin population was the smallest (Table 2; Fig. 3b).

In the superior mesenteric ganglion, Fast Blue/ NPY and Fast Blue/SOM reactive cells were almost equally abundant, but non-immunoreactive cells were rare (Table 3).

In all three experiments, Fast Blue-labelled cells were found evenly distributed in the inferior mesenteric ganglion. Fast Blue/NPY and Fast Blue/SOM cell numbers were more common than Fast Blue only (Table 4).

\section{Proximal colon injections}

In the coeliac ganglion, cells positive for Fast Blue and somatostatin were the most frequent population, these cells were almost exclusively located in the medial part of the ganglion. Fast Blue/NPY cells and Fast Blue cells that were not reactive for either NPY or somatostatin were in about equal proportions and were located preferentially in the lateral parts of the coeliac ganglion.

In the superior mesenteric ganglion, Fast Blue cells were found evenly distributed in small clusters. The majority of cells were Fast Blue/NPY-positive, followed by Fast Blue/somatostatin, the smallest population being the cells positive for Fast Blue but neither NPY nor SOM (Table 3).

In the inferior mesenteric ganglion, Fast Blue positive cells were too few for neurochemical characterization.

\section{Distal colon injections}

Fast Blue-labelled nerve cells were found in the posterior part of the superior mesenteric ganglion, in both lobes of the inferior mesenteric ganglion in greatest numbers, and in hypogastric nerve ganglia anterior to the anterior pelvic ganglia.

In the posterior part of the superior mesenteric ganglion, close to the intermesenteric nerve, Fast Blue/SOM-positive and Fast Blue/NPY-positive cells formed the major populations, whereas Fast Blue- 
cells without NPY and SOM were less frequent (Table 3).

The greatest number of Fast Blue-cells was found in both lobes of the inferior mesenteric ganglion, the majority being immunoreactive for NPY, followed by Fast-Blue cells non-reactive for either NPY or somatostatin, with Fast Blue/SOM nerve cells forming the smallest proportion (Table 4).

\section{Spleen injections}

The majority nerve cells labelled from the spleen were found in paravertebral, rather than prevertebral ganglia. In the coeliac ganglion (and in the superior mesenteric ganglion of the only one of three animals that had Fast Blue cells), all Fast Blue cells were positive for NPY; none was reactive for somatostatin. The same chemistry of splenic neurons has been reported for the rat (CHEVENDRA and WEAVER, 1992).

\section{Labelling from the intermesenteric nerves}

After cutting and dipping the intermesenteric nerves in Fast Blue solution, only very few retrogradely labelled nerve cells were found in the coeliac ganglion (see above) and the proportions of cells with different chemistries were not evaluated.

In the superior and inferior mesenteric ganglia, considerably more Fast Blue containing cells were found (Table 3). About $60 \%$ were not immunoreactive, slightly more than $20 \%$ were immunoreactive for NPY and slightly fewer than $20 \%$ were for somatostatin. Most of those with NPY immunoreactivity were located close to the connection of the intermesenteric nerves.

In the inferior mesenteric ganglia, Fast Blue/NPY positive cells predominated in the superior lobe, as did Fast Blue/- cells in the inferior lobe. Fast Blue/ somatostatin cells were distributed throughout both lobes.

\section{DISCUSSION}

\section{Organotopic trends in prevertebral ganglia}

The present work reveals an organotopic arrangement of nerve cell bodies within and between prevertebral ganglia. Between ganglia, there is a craniocaudal gradient. Mid-gut derivatives and the spleen (which develops in the dorsal mesogastrium) are almost exclusively supplied from the coeliac ganglion; the caecum receives innervation from each of the coeliac, superior mesenteric and inferior mesenteric ganglia; the proximal colon has coeliac and superior mesenteric supplies and the distal colon is primarily innervated from the inferior mesenteric ganglia, with lesser inouts from the superior mesenteric and hypogastric nerve ganglia. Topography within a ganglion is best illustrated by the coeliac. The majority of nerve cells that supply the stomach, duodenum and spleen are lateral in the ganglion, which is consistent with these organs being supplied by the laterally emerging superior coeliac nerves (KREULEN et al., 1983; MESSENGER and FurNESS, 1992). These observations coniirm the distribution tendencies reported by LiNDH et al. (1986), who found that the majority of cells projecting to the pylorus were lateral in the coeliac ganglion, and by JoBLING (1983), who found that cells projecting to the spleen were also lateral. On the other hand, the proximal colon, whose primary supply nerve is the inferior coeliac nerve, is innervated by cells that are predominantly medial in the coeliac ganglion. Some nerve cells in prevertebral ganglia are retrogradely labelled when the intermesenteric nerves are immersed in Fast Blue. This implies that some neurons have axons that run with the intermesenteric nerves, and pass through other prevertebral ganglia before reaching their target organs. However, such transganglionic pathways are taken by a minority of post-ganglionic neurons of prevertebral ganglia (DALSGAARD and ELFVIN, 1982; MCLACHLAN, 1985; BARON and JÄNIG, 1991; PARR et al., 1993; present work).

Neurons that project from the gut to prevertebral ganglia form parts of the afferent limbs of enteroenteric reflexes (SzURSZEWSKI and KING, 1989). Some of these reflexes pass between distant gut regions, for example, the colon and the small intestine, and thus run through up to three prevertebral ganglia: the inferior mesenteric, superior mesenteric and coeliac ganglia (KUNTZ and BUSKIRK, 1934; KING and SZURSZ. EWSKI, 1989; MESSENGER and FURNESS, 1992, 1993). The observation that most postganglionic neurons project directly to their targets implies that many axons of the afferent, intestinofugal, reflex limbs traverse prevertebral ganglia before making synapses with non-adrenergic neurons, as has been concluded from previous studies (KREULEN and SZURSZEWSKI, 1979; LINDH et al., 1988).

\section{Projections from paravertebral ganglia}

This study shows that a minority sympathetic neurons that supply the abdominal gastrointestinal tract are in paravertebral ganglia from $\mathrm{T} 1$ to S1. The neurons have a cranial to caudal sequence in relation to their supply of proximal to distal abdominal gut, which conforms to the pattern previously established (LUNDBERG et al., 1978; KUO and KRAUTHAMER, 1981; 
BARON et al., 1985; JÄNIG and MCLACHLAN, 1987).

\section{Relation of chemotopic and organotopic distributions}

In two previous studies of the coeliac ganglia, it was noted that NPY-immunoreactive nerve cell bodies preferentially lie laterally in the ganglia, whereas somatostatin-immunoreactive neurons are preferentially medial (LiNDH et al., 1986; MACRAE et al., 1986). The noradrenergic neurons that supply vascular tissues are NPY-immunoreactive, whereas the SOMreactive neurons seem to be involved in the control of intestinal fluid transport (COSTA and FURNESS, 1984). The chemical topography may be a consequence of organotopic arrangement of the nerve cells. For example, the spleen, a vascular organ, and the stomach are supplied by lateral nerve cells, whereas the proximal colon, which has a substantial role in fluid resorption, is supplied by medial cells.

\section{Lateral asymmetry}

After some organ injections, cell bodies were selectively labelled on one side. This was notable for the duodenum, which had a majority of cells projecting to it from the right sympathetic chain and right coeliac lobe. The reasons for the asymmetries are unknown, but it is feasible that a contributing factor could be the distribution of dye injections. In the case of the duodenum, only its anterior surface is readily accessible for injection, and all injections were into this surface.

Acknowledgments. We thank Daniela CiAmpoli, Jan POVEY and Heather WoODMAN for their assistance with animal surgery.

\section{REFERENCES}

BARON, R. and W. J̈̈NIG: Afferent and sympathetic neurons projecting into lumbar visceral nerves of the male rat. J. Comp. Neurol. 314: 429-436 (1991).

BARon, R., W. JÄNIG and E. M. McLachlan: The afferent and sympathetic components of the lumbar spinal outflow to the colon and pelvic organs of the cat. III. The colonic nerves. J. Comp. Neurol. 238: 158-168 (1985).

Buchan, A. M. J., L. K. J. Sikova, I. G. Levey, C. H. S. Mcintosh, I. DYck and J. C. Brown: An immunocytochemical investigation with monoclonal antibodies to somatostatin. Histochemistry 83: 175-180 (1985).

Chevendra, V. and L. C. Weaver: Distributions of neuropeptide $\mathrm{Y}$, vasoactive intestinal peptide and somatostatin in populations of postganglionic neurons innervating the rat kidney, spleen and intestine. Neuroscience 50: 727-743 (1992).
Costa, M. and J. B. FuRness: Somatostatin is present in a subpopulation of noradrenergic nerve fibres supplying the intestine. Neuroscience 13: 911-920 (1984).

DAIL, W. G. and S. BARTon: Structure and organization of mammalian sympathetic ganglia. In (ed. by) L.-G. ELFVIN: Autonomic ganglia. John Wiley and Sons Ltd, 1983 (p. 3-25).

DalsgaARD, C.-J. and L.-G. Elfvin: Structural studies on the connectivity of the inferior mesenteric ganglion of the guinea pig. J. Auton. Nerv. Syst. 5: 265-278 (1982).

GIBBINS, I. L.: Vasoconstrictor, vasodilator and pilomotor pathways in sympathetic ganglia of guinea-pigs. Neuroscience 47: 657-672 (1992).

Hill, C. E., I. A. Hendry and A. Sheppard: Use of the fluorescent dye, Fast Blue, to label sympathetic postganglionic neurons supplying mesenteric arteries and enteric neurons of the rat. J. Auton. Nerv. Syst. 18: 7382 (1987).

Hudson, L. C.: The location of extrinsic efferent and afferent nerve cell bodies of the normal canine stomach. J. Auton. Nerv. Syst. 28: 1-14 (1989).

JäNIG, W. and E. M. McLachlan : Organization of lumbar spinal outflow to distal colon and pelvic organs. Physiol. Rev. 67: 1332-1404 (1987).

Jobling, P.: A study of guinea-pig sympathetic neurones with projections to the spleen. Proc. Austral. Neurosci. Soc. 4: 188 (1993).

Keast, J. R., A. M. Booth and W. C. DE GroAt: Distribution of neurons in the major pelvic ganglion of the rat which supply the bladder, colon or penis. Cell Tiss. Res. 256: 105-112 (1989).

King, B. F. and J. H. Szurszewski: Peripheral reflex pathways involving abdominal viscera: Transmission of impulses through prevertebral ganglia. Amer. J. Physiol. 256: G581-G588 (1989).

Kreulen, D. L., T. C. Muir and J. H. Szurszewski: Peripheral sympathetic pathways to gastroduodenal region of the guinea pig. Amer. J. Physiol. 245: G369375 (1983).

Kreulen, D. L. and J. H. Szurszewski: Nerve pathways in coeliac plexus of the guinea pig. Amer. J. Physiol. 237: 90-97 (1979).

Kuntz, A. and C. van Buskirk: Reflex inhibition of bile flow and intestinal motility mediated through decentralized celiac plexus. Proc. Soc. Exp. Biol. Med. 46: 519-523 (1941).

Kuo, D. C. and G. M. KRauthamer: Paravertebral origin of postganglionic sympathetic fibers in the major splanchnic and distal coeliac nerves as demonstrated by horseradish peroxidase (HRP) retrograde transport method. J. Auton. Nerv. Syst. 4: 25-32 (1981).

LANGLEY, J. N.: On the origin from the spinal cord of the cervical and upper thoracic sympathetic fibres, with some observations on white and grey rami communications. Phil. Trans. R. Soc. Lond. (B) 183: 85-124 (1892).

Lichtman, J. W., D. Purves and J. W. YiP: On the purpose of selective innervation of guinea-pig superior cervical ganglion cells. J. Physiol. (Lond.) 292: 69-84 (1979). 
Lindh, B., T. Hökfelt, L.-G. Elfvin, L. Terenius, J. Fahrenkrug, R. Elde and M. Goldstein: Topography of NPY-, somatostatin-, and VIP-immunoreactive, neuronal subpopulations in the guinea pig celiac-superior mesenteric ganglion and their projection to the pylorus. J. Neurosci. 6: 2371-2383 (1986).

LiNDH, B., T. HöKFELT and L.-G. Elfvin: Distribution and origin of peptide-containing nerve fibers in the celiac superior mesenteric ganglion of the guinea-pig. Neuroscience 26: 1037-1071 (1988).

Lundberg, J. M., A. Dahlström, I. Larsson, G. Pettersson, H. Ahlman and J. Kewenter: Efferent innervation of the small intestine by adrenergic neurons from the cervical sympathetic and stellate ganglia, studied by retrograde transport of peroxidase. Acta Physiol. Scand. 104: 33-42 (1978).

MaCCARRone, C. and B. JarrotT: Differences in regional brain concentrations of neuropeptide $\mathrm{Y}$ in spontaneously hypertensive (SH) and Wistar-Kyoto (WKY) rats. Brain Res. 345: 165-169 (1985).

Macrae, I. M., J. B. Furness and M. Costa: Distribution of subgroups of noradrenaline neurons in the coeliac ganglion of the guinea-pig. Cell Tiss. Res. 244: 173-180 (1986).

MCLachlan, E. M.: The components of the hypogastric nerve in male and female guinea pigs. J. Auton. Nerve. Syst. 13: 327-342 (1985).

Messenger, J. P. and J. B. Furness: Distribution of enteric nerve cells that project to the coeliac ganglion of the guinea-pig. Cell Tiss. Res. 269: 119-132 (1992).
- Distribution of enteric nerve cells projecting to the superior and inferior mesenteric ganglia of the guinea-pig. Cell Tiss. Res. 271: 333-339 (1993).

NJÅ, A. and D. Purves: Specific innervation of guineapig superior cervical ganglion cells by preganglionic fibres arising from different levels of the spinal cord. J. Physiol. 264: 565-583 (1977).

Parr, E. J., S. N. Davison, J. S. Davison and K. A. SHARKEY: The origin and distribution of neurons with projections passing through the inferior mesenteric ganglion of the guinea-pig. J. Auton. Nerv. Syst. 44: 9199 (1993).

Romanes, G. J.: The motor pools of the spinal cord. Prog. Brain Res. 11: 93-119 (1964).

Szurszewski, J. H. and B. H. KING: Physiology of the prevertebral ganglia in mammals with special reference to the inferior mesenteric ganglion. In (ed. by) S. G. Schultz, J. D. Wood and B. B. Rauner: Handbook of physiology, Sect 6: The gastrointestinal system, Vol. 1. Amer. Physiol. Soc., Bethesda, 1989 (p. 519-592).

Prof. John B. FURNESS

Department of Anatomy and Cell Biology University of Melbourne

Parkville, Victoria 3052

Australia 